ENVIRONMENTAL SCIENCE

\title{
Impact of Air Pollutants on Agricultural Crops
}

\author{
Alok Singh Jayara
}

Department of Agronomy, College of Agriculture, GBPUA\&T, Pantnagar, Uttarakhand, India

Corresponding email: aloksingh.jayara@gmail.com (ORCID ID: 0000-0002-7882-2018)

Paper No. 885

Received: 03-01-2021

Revised: 25-01-2021

Accepted: 28-02-2021

\begin{abstract}
History of mankind has witnessed transformation in form of industrialization, urbanization and motorized transport in the past. These all had made the life easier for human but these also led to increase in level of pollutants in the atmosphere. These pollutants have cascading impact on agriculture. The impact of some of the major pollutants such as $\mathrm{SO}_{2}$, NOx and ozone is in the form of production of ROS, reduced photosynthesis and energy metabolism. The aerosol and particulate matter pollution also leads to reduced transpiration which raises the canopy temperature and also disturbs the water and nutrient uptake by the crop plants. To date most of the pollution related studies, especially in developing countries, are restricted to its impact on urban areas and human health. It is needed to extend these studies to impact of air pollution on agriculture. In this paper we have discussed the various mechanisms through which the pollutants act on the crop plants and their impact on yield.

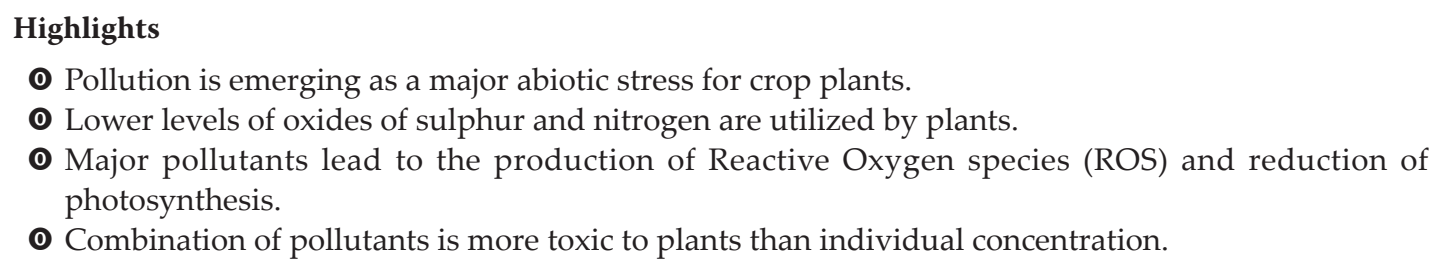

Keywords: Industrialization, urbanization, Reactive Oxygen Species (ROS), photosynthesis, metabolism, aerosols, particulate matter, nutrient uptake, canopy temperature, developing countries

Agriculture has seen the transformation in the past times. There has been increase in the use of technology and improved agronomic practices across the globe, thus, it has been able to satisfy the food demands. Along with these progressive changes, there has also been increase in the biotic and abiotic stress in the crops. Air pollution has emerged as one of the important abiotic stresses in the crops. It represents a major threat to the agriculture system as it has both direct and indirect impacts on the crop. If the substances in atmosphere are present in concentration greater than their normal ambient level such that these causes considerable impact on human, vegetation, materials and animals, it can be called as state of air pollution (Mina et al. 2013). However, the majority of present studies at global and national levels are restricted to the impact of air pollution on human health. One such index is Air Quality Index (AQI) which transforms weighted values of individual air pollution related parameters into a single number and report the air quality with respect to human health (Agarwal and Melkania 2018). There is paucity of studies on the impact of pollutants on the agricultural crops. The air pollutants can be divided into two categories i.e. primary pollutants and secondary pollutants which are directly released into the atmosphere mainly $\mathrm{SO}_{2}, \mathrm{NO}_{x^{\prime}}$ black carbon and particulate matter. Secondary pollutants are those which are formed after the reaction of primary pollutants in the atmosphere.

How to cite this article: Jayara, A.S. 2021. Impact of Air Pollutants on Agricultural Crops. IJAEB, 14(1): 89-95.

Source of Support: None; Conflict of Interest: None (2) क 


\section{PRIMARY POLLUTANTS}

\section{Sulphur dioxide $\left(\mathrm{SO}_{2}\right)$}

Sulphur dioxide is an important primary pollutant. The natural source of $\mathrm{SO}_{2}$ is volcanic eruptions. The man-made sources of $\mathrm{SO}_{2}$ are the burning of fossil fuels by power plants and industries, mining activities, extraction of metal from ore, transport sector, shipping, and locomotives. The largest source of this pollutant is the combustion of fossil fuels in power plants and industries (EPA). The problem of this pollutant is more in the developing countries, which are undergoing rapid industrialization and comparatively higher $\mathrm{S}$ content in the fuels when compared to the developed countries (Ahmed, 2015).

Sulphur is among the essential nutrients to plants. A smaller concentration $\mathrm{SO}_{2}$ can be utilized as the additional source of sulphur by the plants (Kropff, 1991; Agarwal 2003; Muneer et al. 2014). Excess of $\mathrm{SO}_{2}$ causes an increase in respiration and a decrease in photosynthesis due to irregularity in stomatal movement; reduced chlorophyll content and WUE; oxidative damage to the cell membrane and proteins through the production of Reactive Oxygen Species (Lee et al. 2017). $\mathrm{SO}_{2}$ dissolves in apoplastic water to sulphite $\left(\mathrm{SO}_{3}^{2-}\right)$ and bisulphate $\left(\mathrm{HSO}_{3}^{-}\right)$and $\mathrm{H}^{+}$ ions (Agarwal, 2003), which further oxidizes to sulphate and leads to the formation of Reactive Oxygen species (Rai et al. 2011). The sulphate ions are further reduced to sulphide emitted as $\mathrm{H}_{2} \mathrm{~S}$ gas; however, it constitutes 10 percent of the total $\mathrm{SO}_{2}$ absorbed, and the excess sulphate is stored in vacuole, which leads to the reduction of organic anions e.g., malate ions, and ultimately the buffering capacity of the cell is reduced (Kropff 1991). Reactive Oxygen Species (ROS) may act as a signal to induce defense responses to $\mathrm{CO}, \mathrm{NO}_{r^{\prime}}$ and $\mathrm{SO}_{2}$ gas stress in strawberries (Muneer et al. 2014). Sulphur dioxide promotes the opening of the stomata and thus causes excess loss of water (Varshney et al. 1979). Competition between the $\mathrm{CO}_{2}$ and $\mathrm{SO}_{3}^{2-}$ for the active site of Rubisco leads to the inhibition of $\mathrm{CO}_{2}$ fixation in photosynthesis (Rai et al. 2011). $\mathrm{SO}_{2}$ toxicity in leaves is manifested in the form of interveinal lesions on both sides of leaves which may occasionally occur along the margins also. The color of the necrotic area can be light tan to nearly white to an orange-red or brown depending on the season
(Griffiths 2003). Under mild conditions, the wheat leaves show chlorotic pattern due to the loss of chlorophyll, whereas under acute conditions, there is complete breakdown and collapse of leaf cells (Brisley and Jones 1950). Brown to reddish-brown to black blotches on both surfaces of the leaf appears under chronic injury conditions. The root weight of the $\mathrm{SO}_{2}$ treated plants is reduced when compared to the control (Kasana and Mansfield 1986). A very high concentration of $\mathrm{SO}_{2}$ in the atmosphere may lead to acid rain, which can damage foliage over a large area. The effect of excess $\mathrm{SO}_{2}$ is presented in the table 1 .

\section{Nitrogen oxides $\left(\mathrm{NO}_{x}\right)$}

The nitric oxides (NO) and nitrogen dioxide $\left(\mathrm{NO}_{2}\right)$ in combination form nitrogen oxides $\left(\mathrm{NO}_{x}\right)$. Nitric oxide after oxidation leads to the formation of nitrogen dioxide. The major sources of nitrogen oxides are emissions from transport, industries, and power plants. The major anthropogenic sources of $\mathrm{NO}_{x}$ emission are fossil fuel combustion (70 percent), of which transport and power sector are major contributors; biomass burning (20 percent); industrial process (5 percent), and bio-fuel use (5 percent) (Olivier et al. 1998). It is also formed naturally by the oxidation of nitrogen under the influence of lightning and microbial processes. The industrial and vehicular emissions constitute the point source whereas, agriculture constitutes the non-point source of emission. Global studies have pointed to similarities in the magnitude of $\mathrm{NO}_{\mathrm{x}}$ emissions from fossil fuel combustion and soil, with the largest soil emissions from regions with heavy $\mathrm{N}$ fertilizer applications (Alamaraz 2018).

A lower amount of $\mathrm{NO}_{\mathrm{x}}$ is utilized by the plant in nitrate assimilation pathway and form organic nitrogenous compounds (Sheng and Zhu 2019). It is also observed that plants supplied with good soil N, have better uptake of nutrients, increase the rate of photosynthesis, shoot biomass, and total leaf area under exposure to gaseous $\mathrm{NO}_{2}$ (Takahashi and Morikawa 2014). However, Srivastava and Ormrod, (1984) reported the inhibitory effect of increasing $\mathrm{NO}_{2}$ levels along with the nutrient nitrates in beans. Among the two $\mathrm{NO}_{x^{\prime}} \mathrm{NO}$ proves to be more phytotoxic than $\mathrm{NO}_{2}$ and also acts more rapidly on the inhibition of photosynthesis (Air quality guidelines- $\mathrm{II}$ edn). $\mathrm{NO}_{\mathrm{x}}$ enters the plant through 
Table 1: Collection of various studies representing effect of $\mathrm{SO}_{2}$ pollutant (at different concentrations) on some agricultural crops

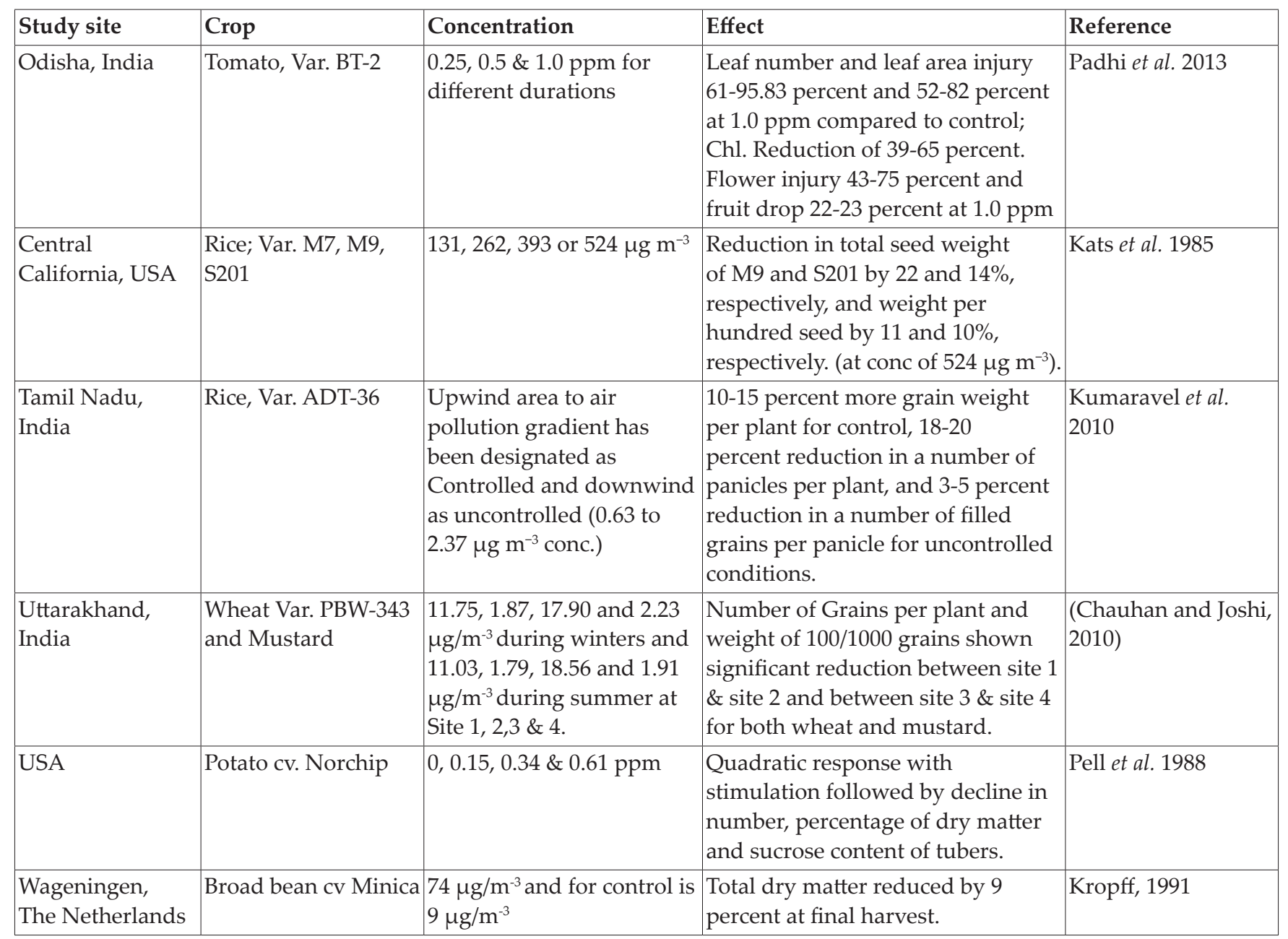

the stomata as similar to $\mathrm{SO}_{2}$ and, after dissolving in the aqueous phase of apoplast, either reduced to produce nitrous acid $\left(\mathrm{HNO}_{2}\right)$ or dissociate to produce nitrate $\left(\mathrm{NO}_{3}^{-}\right)$or nitrite $\left(\mathrm{NO}_{2}^{-}\right)$(Rai et al. 2011). These nitrate and nitrite are potent for the production of free radicals, causing the oxidation of lipids and membranes. A higher concentration of $\mathrm{NO}_{2}$ leads to the reduction of chlorophyll content, cell acidification, and generation of toxic ROS, leading to the whole plant chlorosis and even death (Sheng and Zhu 2019). The $\mathrm{NO}_{x}$ also undergoes photochemical changes which lead to the formation of ozone in the troposphere, which is a secondary pollutant. Very little research has been carried out on the impact of $\mathrm{NO}_{2}$ on crop yields in developing countries (Ahmed 2015). The studies regarding the impact of the $\mathrm{NO}_{2}$ pollution on the crops are in table 2 .

\section{Other Primary pollutants}

The other major primary air pollutants are particulate matter, fluorides, and ammonia. Particulate matter is the broad group of suspended materials in the atmosphere comprising liquid droplets, soot, dirt, and smoke. The chemical composition of particulate matter includes nitrates; ammonium; sulfates, other inorganic ions such as ions of $\mathrm{K}, \mathrm{Na}, \mathrm{Ca}, \mathrm{Mg}$ and $\mathrm{Cl}$, organic and elemental carbon; crustal material; particle-bound water; metals (including $\mathrm{Cd}, \mathrm{Cu}, \mathrm{Ni}$, $\mathrm{V}$, and Zn); and polycyclic aromatic hydrocarbons (PAH) (Noh et al. 2019). These deposit on the leaf surface and block the stomata on the leaves. The alkaline particulate matter causes leaf surface injury, whereas the other takes across the cuticle; further particulate matter reduces the light interception for photosynthesis and increases the leaf temperature (Rahul and Jain 2014). The particulate matter hinders 
Table 2: Collection of various studies representing effect of NOx pollutant (at different concentrations) on some agricultural crops

\begin{tabular}{|l|l|l|l|l|}
\hline Study site & Crop & Concentration & Effect & Reference \\
\hline Pakistan & Rice & $20-25 \mathrm{ppb}$ & $37-51$ percent yield reduction & Maggs et al. 1995 \\
\hline Pakistan & Rice & $12 \mathrm{nl} /$ liter & 37 \& 42 percent yield reduction in two cultivars & Wahid et al. 1995 \\
\hline Pakistan & Wheat & $20-25 \mathrm{ppb}$ & $33-46$ percent yield reduction & Maggs et al. 1995 \\
\hline USA & $\begin{array}{l}\text { Phaseolus } \\
\text { vulgaris \& } \\
\text { Lycopersicon } \\
\text { esculentum }\end{array}$ & $\begin{array}{l}<1.03 \mathrm{mg} / \mathrm{m}^{3} \text { for } \\
10-22 \text { days }\end{array}$ & $\begin{array}{l}\text { Growth suppression, increase in green color, and } \\
\text { distortion of leaves. }\end{array}$ & $\begin{array}{l}\text { Taylor and Eaton } \\
1966\end{array}$ \\
\hline USA & Soybean & 0.1 to $0.5 \mu \mathrm{l} /$ liter & $\begin{array}{l}23 \text { and } 50 \text { per cent reduction in Net Photosynthetic rate } \\
\text { after } 5 \text { days of exposure of } 0.5 \mu 1 / \text { liter and } 24 \text { hours } \\
\text { after termination of exposure. } 45 \text { and } 47 \text { per cent Chl } \\
\text { a reduction compared to total chl, respectively. } 47 \text { and } \\
51 \text { per cent reduction of RGR and NAR, respectively at } \\
0.5 \mu l / \text { liter exposure. }\end{array}$ & Gupta 1988. \\
\hline
\end{tabular}

the entry of $\mathrm{CO}_{2}$ through blockage of stomata; accumulates the heavy metals in edible crops and thus, disturbing the levels of the food chain (Noh et al. 2019). Particulate matter leads to the reduction of total chlorophyll content (Rathore et al. 2018), net assimilation efficiency, retarded leaf growth in the long run, abrasive effect in case of high winds leading to the removal of protective cuticle and thus, exposing leaf surface to the pest incidence (Ulrichs et al. 2008). The visible symptoms differ according to the particulate matter e.g. Cement dust may cause chlorosis and death of the plant (Griffiths 2003). One of the atmospheric pollutants is fluoride. It causes an altered pattern of oxygen uptake and $\mathrm{CO}_{2}$ metabolism and appears as marginal chlorosis followed by necrosis (Weinstein and McCune 1971).

\section{SECONDARY POLLUTANTS}

Secondary pollutants are those which are formed after the transformation of the primary pollutants. These are not emitted directly into the air but are formed in the atmosphere by chemical reactions between atmospheric gases and other pollutants. The burning of fossil fuels leads to the emission of $\mathrm{CO}_{2}$, NOx, and volatile organic compounds, which act as primary precursors for ozone formation (Mauzerall and Wang 2001). The ozone formation is promoted in the areas having high light intensity and temperature and thus, favored in the low latitude developing countries.

The major physiological effects of ozone uptake in plants are reduced stomatal conductance and net photosynthesis (Ainsworth 2016), increased senescence (Mauzerall and Wang 2001), and multiple exposures of ozone to B. campestris had led to a significant effect on seed abortion (Stewart et al. 1996). The ozone uptake by plants causes the formation of ROS, including singlet oxygen in the apoplast (Ainsworth 2016) which first target the plasma membrane lipids and amino acids in plasma membrane proteins (Emberson et al. 2018); an inhibitory effect on phloem loading and thus, causes assimilate saturation at source (Rai et al. 2011) and thus, reduces the translocation of fixed carbon to the edible parts (Wilkinson et al. 2012). The plants show different defense mechanisms against ROS ranging from the production of anti-oxidant compounds like ascorbate, $\beta$-carotene, glutathione to; activity of enzymes such as SOD, ascorbate peroxidase; production of mon-terpenes to the increase in the respiratory rates of mitochondria (Emberson et al. 2018). Ozone toxicity leads to pollen sterility and pollen abortion; reduces the capability of the plants to face drought stress or high vapor pressure deficit (Wilkinson et al. 2012). High ozone also reduces the concentration Rubisco required for the dark reaction of photosynthesis (Emberson et al. 2018). The symptoms of ozone injury appear as chlorosis and necrosis of leaves, and additional symptoms appear as flecks, stipples, bronzing, and reddening. The effect of ozone on some of the crops is given in table 3 .

In addition to the individual effects, it is important to study the combined effect of all the pollutants as these are not separated by water-tight compartments, and sources of the majority of pollutants are common. Foster et al. (1983) reported significant $\mathrm{O}_{3} \times \mathrm{SO}_{2}$ interactions where $\mathrm{SO}_{2}$ intensified the 
Table 3: Collection of various studies representing effect of ozone pollutant (at different concentrations) on some agricultural crops

\begin{tabular}{|c|c|c|c|c|}
\hline Study site & Crop & Concentration & Effect & Reference \\
\hline $\begin{array}{l}\text { New Delhi, } \\
\text { India }\end{array}$ & $\begin{array}{l}\text { Wheat var. HD-2967 } \\
\text { and C-306 }\end{array}$ & $70 \mathrm{ppb}$ & $\begin{array}{l}\text { Decrease in LAI by } 5.1-12.5 \text { percent; } \\
\text { photosynthetic rate by } 2.8-11.8 \text { percent and } \\
\text { yield by } 2.2-14.2 \text { percent over ambient one } \\
\text { (30.7ppb conc.) }\end{array}$ & $\begin{array}{l}\text { Yadav et al. } \\
2019\end{array}$ \\
\hline North India & $\begin{array}{l}\text { Wheat (T. aestivum } \\
\text { var PBW-343 and } \\
\text { T. durum var. HD- } \\
\text { 2936) }\end{array}$ & $\begin{array}{l}\text { 25-33 ppb over non-filtered } \\
\text { air }\end{array}$ & $\begin{array}{l}\text { 15-19 percent yield reduction in T. aestivum } \\
\text { and 9-13 percent in T. durum. Reduction of } \\
\text { a number of leaves, chlorophyll, rubisco } \\
\text { activity, and leaf area index in both species; } \\
\text { however, T. aestivum was found more } \\
\text { susceptible. }\end{array}$ & $\begin{array}{l}\text { Tomar et al. } \\
2015\end{array}$ \\
\hline Japan & $\begin{array}{l}\text { Rice var. } \\
\text { Koshihikari }\end{array}$ & $\begin{array}{l}1.0 \text { and } 1.5 \text { times the } \\
\text { ambient } \mathrm{O}_{3} \text { concentration } \\
\text { under standard nitrogen } \\
\text { dose }\end{array}$ & $\begin{array}{l}\text { Significant reduction in dry matter in plants } \\
\text { under } 1.5 \times \mathrm{O}_{3} \text { than } 1.0 \times \mathrm{O}_{3} \text {. }\end{array}$ & $\begin{array}{l}\text { Tatsumi et al. } \\
2019\end{array}$ \\
\hline $\begin{array}{l}\text { California, } \\
\text { USA }\end{array}$ & $\begin{array}{l}\text { Barley var CM-72 } \\
\text { \& Poco }\end{array}$ & $\begin{array}{l}2 \text { times the ambient conc } \\
(\text { ambient conc was } 0.03-0.05 \\
\left.\mu l \text { litre }^{-1}\right)\end{array}$ & $\begin{array}{l}\text { No effect on the growth and yield of both } \\
\text { cultivars }\end{array}$ & $\begin{array}{l}\text { Temple et al. } \\
1985\end{array}$ \\
\hline
\end{tabular}

leaf symptoms of $\mathrm{O}_{3}$ treated potato plants, and there was increased $\mathrm{O}_{3}$ induced $\mathrm{N}$-content in tuber with the presence of $\mathrm{SO}_{2} \cdot \mathrm{NO}_{2}$ and $\mathrm{SO}_{2}$ are found in combination in the industrial areas, and their combined effect is underestimated when considered as separate or the combined effect will be greater than estimated as separate (Mansfield et al. 1982).

\section{CONCLUSION}

Growing pollution is the major concern of the countries around the world; however, the developing countries are at more risk owing to the fewer resources and socio-economic vulnerability. The critical pollutants i.e. $\mathrm{SO}_{2}, \mathrm{NOx}$, and ozone, have the potential to disrupt the global food supply. Projecting ozone emissions for 2025, the high-risk area expands dramatically, covering the majority of the cultivated areas of India, China, Egypt, South Africa, and significant areas in other countries (Marshall et al.). Developing of an index for easy measurement of the impact of pollution for screening crops and cultivars in terms of their tolerance to air pollution is required. Air Pollution Tolerance Index (APTI) is one such index where total chlorophyll, relative water content, ascorbic acid content, and $\mathrm{pH}$ value of leaf extract is measured for its calculation, and higher value refers to the tolerance to the pollutant (Rathore et al. 2018). There is an imbalance in assessment between the developed and developing world for the losses in the agriculture production due to the air pollution being accumulated over decades. There is an urgent 
need to expand the research and assessment to all the continents as the pollutants are not restricted to one place and can threaten the global food supply chain.

\section{REFERENCES}

Agrawal, M. 2003. Plant Responses to Atmospheric Sulphur. In: Sulphur in Plants, Abrol Y.P., Ahmad A. (eds). Springer, Dordrecht, pp. 279-293.

Agarwal, P. and Melkania, U. 2018. Assessment of the Ambient Air Quality at the Industrial Area using the Air Quality Index Method (AQI). Int. J. Agric. Environ. Biotech., 11(2): 227-234.

Ahmed, S. 2015. Air pollution and its impact on agricultural crops in developing countries- a review. J. Anim. Plant Sci., Spl issue 25(3 Supp. 2): 297-302.

Ainsworth, E.A. 2016. Understanding and improving global crop response to ozone pollution. Plant J., Special Issue: Plant Abiotic Stress, 90(5): 886-897.

Almaraz, M., Bai, E., Wang, C., Trousdell, J., Conley, S., Faloona, I. and Houlton, B.Z. 2018. Agriculture is a major source of NOx pollution in California. Sci. Adv., 4(1): eaao3477.

Brisley, H.R. and Jones, W.W. 1950. Sulphur dioxide fumigation of wheat with special reference to its effect on yield. Pl. Physiol., 25(4): 666-681.

Chauhan, A. and Joshi, P.C. 2010. Effect of ambient air pollutants on wheat and mustard crops growing in the vicinity of urban and industrial areas. N Y Sci. J., 3(2): $52-60$

Chen, Z., Wang, X., Feng, Z., Zheng, F., Duan, X. and Yang, W. 2008. Effects of elevated ozone on growth and yield of field-grown rice in Yangtze River Delta, China. J Environ Sci (China)., 20(3): 320-325.

Emberson, L.D., Pleijel, H., Ainsworth, E.A., Berg, M., Ren, W., Osborne, S., Mills, G., Pandey, D., Dentener, F., Büker, P., Ewert, F., Koeble, R. and Dingenen, R.V. 2018. Ozone effects on crops and consideration in crop models. Eur. J. Agron., 100: 19-34.

Fosters, K.W., Timm, H., Labanauskas, C.K., Oshima, R.J. 1983. Effect of ozone and sulphur dioxide on tuber yield and qualities of potatoes. J. Environ. Qual., 12(1): 75-80.

Griffiths, H. 2003. Revision of Factsheet Air Pollution on Agricultural Crops, Order No. 85-002; Printed June, 2003.

Kasana, M.S. and Mansfield, T.A. 1986. Effects of air pollutants on the growth and functioning of roots. Proc. Indian Acad. Sci. (Plant Sci.)., 96(6): 429-441.

Kats, G., Dawson, P. J., Bytnerowicz, A., Wolf, J.W., Thompson, C.R. and Olszyk, D.M. 1985. Effects of ozone or sulfur dioxide on growth and yield of rice. Agric. Ecosyst. Environ., 14(1-2): 103-117.

Kropff, M.J. 1991. Long-term effects of $\mathrm{SO}_{2}$ on plants, $\mathrm{SO}_{2}$ metabolism and regulation of intracellular $\mathrm{pH}$. Plant Soil., 131: 235-245.

Kumaravel, B., Palanivelraja, S. and Sivakumar, K. 2010. Effect of Emission from Thermal Power Stations on Growth and Yield of Rice Crop at Selected Rural Sites in Cuddalore District of Tamil Nadu. Nat. Environ. Pollut. Technol., 9(1): 13-18.

Lee, H.K., Khaine, I., Kwak, M.J., Jang, J.H., Lee, T.Y., Lee, J.K., Kim, I.R., Kim, W.I. Oh, K.S. and Woo, S.Y. 2017. The Relationship between $\mathrm{SO}_{2}$ Exposure and Plant Physiology: A Mini Review. Hortic. Environ. Biotechnol., 58(6): 523-529.

Maggs, R., Wahid, A., Shamsi, S.R.A. et al. 1995. Effects of ambient air pollution on wheat and rice yield in Pakistan. Water Air Soil Pollut., 85: 1311-1316.

Mansfield, T.A., Whitmore, M.E. and Law, R.M. 1982. Editor(s): T. Schneider, L. Grant. Effects of Nitrogen Oxides on Plants: Two Case Studies. Stud. Environ. Sci. 21: 511-520.

Marshall, F., Ashmore, M. and Hinchcliffe, F. A hidden threat to food production: Air pollution and agriculture in the developing world. Gatekeeper series no 73.

Mauzerall, D.L. and Wang, X. 2001. Protecting agricultural crops from the effects of tropospheric ozone exposure: Reconciling Science and Standard Setting in the United States, Europe, and Asia. Annu. Rev. Energ. Environ., 26: 237-68.

Mina, U., Kumar, P. and Varshney, C.K. 2010. Response of different growth stages of potato (Solanum tuberosum) to ozone stress. Phyton., 49: 253-266.

Mina, U., Sigh, R. and Chakrabarti, R. 2013. Agricultural Production and Air Quality: An Emerging Challenge. Int. J. Environ. Sci. Dev. Monit., 4(2): 80-85.

Muneer, S., Kim, T.H., Choi, B.C., Lee, B.S., and Lee, J.H. 2014. Effect of $\mathrm{CO}, \mathrm{NOx}$ and $\mathrm{SO}_{2}$ on ROS production, photosynthesis and ascorbate-glutathione pathway to induce Fragaria $\times$ annasa as a hyperaccumulator. Redox Biol., 2: 91-98.

Noh, K., Thi, L.T. and Jeong, B.R. 2019. Particulate matter in the cultivation area may contaminate leafy vegetables with heavy metals above safe levels in Korea. Environ. Sci. Pollut. Res., 26: 25762-25774.

Olivier, J.G.J., Bouwman, A.F., Van der Hoek, K.W. and Berdowski, J.J.M. 1998. Global air emission inventories for anthropogenic sources of NOx, $\mathrm{NH}_{3}$ and $\mathrm{N}_{2} \mathrm{O}$ in 1990. Environ. Pollut., 102(1): 135-148.

Padhi, S.K., Dash, M. and Swain, S.C. 2013. Effect of sulphur dioxide on growth, chlorophyll and sulphur contents in tomato (Solanum lycopersicum L.). Eur. Sci. J., 9(36): 465-171.

Pell, E.J., Pearson, N.S. and Vinten-Johansen, C. 1988. Qualitative and quantitative effects of ozone and/or sulfur dioxide on field-grown potato plants. Environ. Pollut., 53(1-4): 171-86.

Rahul, J. and Jain, M.K. 2014. An Investigation in to the Impact of Particulate Matter on Vegetation along the National Highway: A Review. Res. J. Environ. Sci., 8(7): 356-372.

Rai, R., Rajput, M., Agarwal, M. and Agarwal, S.B. 2011. Gaseous air pollutants: A review on current and future trends of emission and impact on agriculture. J. Sci. Res., 55: 77-102. 
Rathore, D.S., Kain, T. and Gothalkar, P. 2018. A Study of Air Pollution Status by Estimation of APTI of Certain Plant Species Around Pratapnagar Circle in Udaipur City. Int. J. Agric. Environ. Biotechnol., 11(1): 33-38.

Sabaratnam, S. and Gupta, G. 1988. Effects of nitrogen dioxide on biochemical and physiological characteristics of soybean. Environ. Pollut., 55(2): 149-158.

Sheng, Q. and Zhu, Z. 2019. Effects of Nitrogen Dioxide on Biochemical Responses in 41 Garden Plants. Plants, 8(2): 45.

Srivastava, H.S. and Ormrod, D.P. 1984. Effects of Nitrogen Dioxide and Nitrate Nutrition on Growth and Nitrate Assimilation in Bean Leaves. Plant Physiol., 76: 418-423.

Stewart, C. A., Black, V. J., Black, C.R. and Roberts, J.A. 1996. Direct effects of ozone on the reproductive development of Brassica species. J. Plant Physiol., 148(1-2): 172-178.

Takahashi, M. and Morikawa, H. 2014. Nitrogen dioxide is a positive regulator of plant growth. Plant Signal. Behav., 9(2): e28033.

Tatsumi, K., Abiko, T., Kinose, Y., Inagaki, S. and Izuta, T. 2019. Effects of ozone on the growth and yield of rice (Oryza sativa L.) under different nitrogen fertilization regimes. Environ. Sci. Pollut. Res. Int., 26(31): 32103-32113.

Taylor, O.C. and Eaton, F.M. 1966. Suppression of plant growth by nitrogen dioxide. Pl. Physiol., 41(1): 132-135.

Temple, P. J., Taylor, O.C. and Benoit, L.F. 1985. Effects of ozone on yield of two field-grown barley cultivars. Enivron. Pollut. A., 39(3): 217-225.
Tomer, R., Bhatia, A., Kumar, V., Kumar, A., Singh, R., Singh, B. and Singh, S. 2015. Impact of Elevated Ozone on Growth, Yield and Nutritional Quality of Two Wheat Species in Northern India. Aerosol Air Qual. Res., 15: 329-340.

Ulrichs, C., Welke, B., Mucha-Pelzer, T., Goswami, A. and Mewis, I. 2008. Effect of solid particulate matter deposits on vegetation- A review. Funct. Plant Sci Biotechnol., 2(1): 56-62.

Varshney, C.K., Garg, J.K., Lauenroth, W.K. and Heitschmidt, R.K. 1979. Plant responses to sulfur dioxide pollution, $C$ R C Crit. Rev. Environ. Control., 9(1): 27-49.

Wahid, A., Maggs, R., Shamsi, S.R.A., Bell, J.N.B. and Ashmore, M.R. 1995. Effects of air pollution on rice yield in the Pakistan Punjab. Environ. Pollut., 90(3): 323-329.

Weinstein, L.H. and McCune, D.C. 1971. Effects of Fluoride on Agriculture. J. Air Pollut. Control Assoc., 21(7): 410-413.

Wilkinson, S., Mills, G., Illidge, R. and Davies, W. J. 2012. How is ozone pollution reducing our food supply? J. Exp. Bot., 63(2): 527-536.

Yadav, A., Bhatia, A., Yadav, S., Kumar, V. and Singh, B. 2019. The effects of elevated $\mathrm{CO}_{2}$ and elevated $\mathrm{O}_{3}$ exposure on plant growth, yield and quality of grains of two wheat cultivars grown in north India. Heliyon, 5(8): e02317. 
